\title{
URGENSI STRATEGI DISPOSITION HABITS OF MIND MATEMATIS
}

\author{
Oleh: \\ Bety Miliyawati \\ Mahasiswa Pascasarjana, Universitas Pendidikan Indonesia \\ betylia83@gmail.com
}

\begin{abstract}
ABSTRAK
Kebiasaan berpikir (habits of mind) memiliki peranan penting dalam proses pembelajaran dan perkembangan individu dalam membantu memecahkan masalah. Habits Of Mind (HOM) adalah kebiasaan berpikir secara fleksibel, mengelola secara empulsif, mendengarkan dengan empati, membiasakan mengajukan pertanyaan, kebiasaan menyelesaikan masalah secara efektif, membiasakan menggunakan pengetahuan masa lalu untuk situasi baru, membiasakan berkomunikasi, berpikir jernih dengan tepat, menggunakan semua indera ketika mengumpulkan informasi, mencoba cara berbeda dan menghasilkan ide-ide yang baru, kebiasaan untuk merespon, kebiasaan untuk mengambil resiko, biasa bertanggung jawab, memiliki rasa humor, membiasakan berpikir interaktif dengan orang lain, bersikap terbuka dan mencoba terus-menerus. Hal ini sejalan dengan tujuan Kurikulum 2013, yaitu mempersiapkan generasi bangsa agar memiliki kemampuan hidup sebagai pribadi dan warga negara yang produktif, kreatif, inovatif, dan afektif. Artikel ini dikaji didasarkan atas analisis terhadap: (1) karakteristik matematika, (2) habits of mind matematis, dan (3) disposition contoh strategi HOM dalam pembelajaran matematika yang dikembangkan pada siswa.
\end{abstract}

Kata Kunci : Pembelajaran, Karakteristik Matematika, Habits of Mind Matematis

\begin{abstract}
Habits of mind have an important role in the learning process and the development of individuals in helping to solve the problem. Habits Of Mind (HOM) is the habit of thinking flexibly, manage empulsif, listening with empathy, get used to ask questions, solve problems effectively habit, the habit of using past knowledge to new situations, to get used to communicate, think clearly, precisely, using all the senses when gathering information, trying different ways and generate new ideas, habits to respond, the habit to take risks, the usual charge, have a sense of humor, familiarize interactive thinking with others, be open and try constantly. This is in line with the curriculum goals in 2013, which is preparing a generation of people that have the ability to live as individuals and productive citizens, creative, innovative, and affective. This article is assessed based on an analysis of: (1) the characteristics of mathematics, (2) the mathematical habits of mind, and (3) disposition example HOM in mathematics learning strategies developed in students.
\end{abstract}

Keywords: Learning, Mathematics Characteristics, Habits of Mind Mathematics 


\section{PENDAHULUAN}

Matematika sebagai salah satu disiplin ilmu mempunyai peranan penting dalam mengembangkan kemampuan peserta didik termasuk kemampuan berpikirnya. Hal ini sesuai dengan Standar Nasional Pendidikan bahwa tujuan pembelajaran matematika diharapkan dapat memberikan penataan nalar, berpikir kritis, pembentukan sikap siswa serta kemampuan penerapannya dalam kehidupan seharihari maupun dalam mempelajari berbagai ilmu pengetahuan (Depdiknas, 2004). Menurut Ruseffendi dalam (Miliyawati, 2012) menyatakan bahwa matematika terbentuk sebagai hasil pemikiran manusia yang berhubungan dengan ide, proses, dan penalaran. Dengan kata lain, matematika sebagai ilmu yang mengembangkan sikap berpikir kritis, dinamis, dan terbuka tidak dapat dipisahkan dengan penalaran. Hal ini sejalan dengan tujuan Kurikulum 2013, yaitu mempersiapkan generasi bangsa agar memiliki kemampuan hidup sebagai pribadi dan warga negara yang produktif, kreatif, inovatif, dan afektif.

Mahmudi (2010 : 5) menyatakan bahwa salah satu cara yang dapat dilakukan untuk mencapai tujuan tersebut di atas adalah dengan membiasakan siswa pada semua jenjang pendidikan untuk mengembangkan kemampuan berpikir matematis. Dengan kata lain, pengembangan kemampuan berpikir matematika bersifat untuk semua siswa (mathematics for all), karena kemampuan berpikir matematis, sering dianggap sebagai tujuan utama dalam pembelajaran matematika. Goldenberg et.al (2002) menyatakan bahwa "berpikir" adalah inti dari semua pembelajaran di sekolah. Goldenberg lebih jauh mengemukakan bahwa matematika adalah suatu disiplin ilmu yang komponen utamanya adalah berpikir. Karena itu, urgensi kebiasaan berpikir matematis perlu dilakukan melalui pembelajaran matematika yang secara substansial memuat pengembangan kemampuan berpikir yang berlandaskan pada kaidah-kaidah penalaran secara logis, kritis, sistematis, dan akurat.

Dipihak lain, Umar (2013 : 12) menyatakan bahwa kemampuan yang harus dikembangkan dalam pembelajaran matematika tidak hanya mencakup kemampuan kognitif tetapi juga kemampuan afektif, harus dimiliki oleh setiap siswa. Menurut Mullis (2013) mengungkapkan bahwa terdapat hubungan yang positif antara sikap dengan prestasi matematika. Sedangkan menurut Slavin (2000) mengungkapkan bahwa seseorang dianggap telah belajar sesuatu jika dia dapat menunjukkan perubahan perilakunya. Hal ini menunjukkan bahwa orientasi dari pembelajaran selain mengembangkan pengetahuan dan keterampilan siswa, yaitu mengembangkan sikap. Sikap merupakan faktor yang sangat mempengaruhi perilaku atau aksi seseorang dalam menghadapi tugas, termasuk tugas akademik. Ini berarti bahwa dalam proses pembelajaran matematika, ranah sikap perlu dan terus ditumbuhkembangkan secara optimal pada diri siswa. Hal ini dikarenakan dalam belajar matematika dan menjalani kehidupan sehari-hari, siswa selalu berhadapan dengan multi persoalan. Untuk merespon dan mencari solusi terutama masalah yang kompleks diperlukan disposisi yang kuat dan perilaku cerdas. 
Costa dan Kallick (2008) menamakan disposisi yang kuat dan perilaku cerdas dengan istilah kebiasaan berpikir (habits of mind). Melalui disposisi yang kuat dan perilaku cerdas maka mereka akan mampu menghadapi beragam persoalan hidup dan kehidupan mulai dari tingkat sederhana sampai dengan yang sangat kompleks secara mandiri dengan penuh rasa percaya diri. Dengan demikian, seorang guru matematika perlu berupaya secara maksimal agar siswa memiliki kemampuan disposisi dan perilaku cerdas dengan melakukan variasi proses pembelajaran baik pendekatan, metode, atau model pembelajaran yang inovatif sehingga tujuan yang dicanangkan berhasil dicapai melalui kurikulum matematika.

Tugas seorang guru adalah membantu siswanya mendapatkan informasi, ide - ide, keterampilan - keterampilan, nilai - nilai, dan cara - cara berpikir serta mengemukakan pendapat. Namun, tugas guru yang paling penting dan menentukan adalah membimbing para siswa tentang bagaimana menumbuhkembangkan habits of mind matematis, yaitu kebiasaan berpikir secara fleksibel, mengelola secara empulsif, mendengarkan dengan empati, membiasakan mengajukan pertanyaan, kebiasaan menyelesaikan masalah secara efektif, membiasakan menggunakan pengetahuan masa lalu untuk situasi baru, membiasakan berkomunikasi, berpikir jernih dengan tepat, menggunakan semua indera ketika mengumpulkan informasi, mencoba cara berbeda dan menghasilkan ide-ide yang baru, kebiasaan untuk merespon, kebiasaan untuk mengambil resiko, biasa bertanggung jawab, memiliki rasa humor, membiasakan berpikir interaktif dengan orang lain, bersikap terbuka dan mencoba terus-menerus. Karena itu, tujuan jangka panjang pembelajaran adalah untuk meningkatkan kemampuan para siswa agar ketika mereka sudah meninggalkan bangku sekolah, mereka akan mampu mengembangkan diri mereka sendiri dan mampu menyelesaikan masalah yang muncul.

Sebagai dasar pijakan, maka artikel ini dimaksudkan untuk mengkaji strategi disposition habits of mind matematis sesuai dengan kaidah-kaidah teori, yang dapat dikembangkan pada siswa dan disertai dengan contoh pembelajarannya.

\section{KAJIAN TEORI}

\section{Karakteristik Matematika}

Standar proses dalam kurikulum Nasional, menegaskan bahwa pembelajaran matematika hendaknya lebih ditekankan pada pengembangan potensi yang dimiliki peserta didik antara lain kreativitas, kebiasaan bekerja keras dan mandiri, jujur, berdisiplin, memiliki sikap sosial yang baik, serta berbagai kompetensi dasar matematika agar mereka dapat hidup bermasyarakat dan menjadi warga negara yang melek matematika (Depdiknas, 2004). Untuk memenuhi harapan di atas dan mengantisipasi berbagai perubahan dimasa mendatang, perlu kiranya para pendidik 
terus memperbahrui dan mengembangkan berbagai aspek dalam pembelajaran matematika. Melalui kegiatan matematika ("doing mathematics") memberikan sumbangan yang penting dalam pengembangan nalar yang diperlukan dalam upaya membekali lulusan yang berpikir logis, sistematis, kritis dan cermat, serta sikap objektif dan terbuka dalam menghadapi berbagai permasalahan.

Apabila kita cermati, setiap orang dalam hidupnya tidak terlepas dari proses "doing mathematics", mulai dari bentuk yang sederhana dan rutin sampai pada bentuknya yang sangat kompleks. Misalnya, menghitung dan membilang, dua contoh kegiatan matematika rutin dan sederhana, hampir dikerjakan oleh setiap orang. Dua contoh kegiatan matematika lainnya, "mathematical problem solving" dan "mathematical reasoning" dikerjakan oleh sekelompok orang tertentu saja. Keadaan tersebut melukiskan karakteristik matematika sebagai suatu kegiatan manusia atau "mathematics as a human activity". Sejalan dengan sifat kegiatan manusia yang tidak statis, pandangan tersebut memuat makna bahwa matematika sebagai suatu proses yang aktif, dinamik, dan generatif (Sumarmo, $2010: 3$ )

Karakteristik matematika lainnya adalah sebagai bahasa simbol yang efisien, serta memiliki sifat keteraturan yang indah dan kemampuan analisis kuantitatif, yang membantu menghasilkan model matematika yang diperlukan dalam pemecahan masalah berbagai cabang ilmu pengetahuan dan masalah kehidupan sehari-hari. Disisi lain, matematika sebagai kegiatan manusia yang memiliki sifat menekankan pada proses deduktif yang memerlukan penalaran logis dan aksiomatik, yang diawali dengan proses induktif yang meliputi penyusunan konjektur, model matematika, analogi dan atau generalisasi, melalui pengamatan terhadap sejumlah data. Karakteristik berikutnya, ditinjau dari segi susunan unsur-unsurnya, matematika dikenal pula sebagai ilmu yang terstruktur dan sistimatis dalam arti bagian-bagian matematika tersusun secara hierarkhis dan terjalin dalam hubungan fungsional yang erat. Keunggulan matematika pada pernyataan di atas juga melukiskan karakteristik matematika sebagai ilmu yang terstruktur dan sistimatis, dengan memggunakan bahasa simbol serta sebagai alat bantu dalam menyelesaikan masalah kehidupan sehari-hari dan ilmu-ilmu lainnya.

Karakteristik matematika di atas, mengarahkan visi matematika pada dua arah pengembangan yaitu untuk memenuhi kebutuhan masa kini dan kebutuhan masa datang. Visi pertama mengarahkan pembelajaran matematika untuk pemahaman konsep dan idea matematika yang kemudian diperlukan untuk menyelesaikan masalah matematika dan ilmu pengetahuan lainnya. Visi kedua dalam arti yang lebih luas dan mengarah ke masa depan, matematika memberi peluang bagaimana kebiasaan berpikir (habits of mind) untuk berkembangnya "kemampuan berpikir logis, sistimatis, kritis dan cermat, kreatif, menumbuhkan rasa percaya diri, dan rasa keindahan terhadap keteraturan sifat matematika, serta mengembangkan sikap obyektif dan terbuka" yang sangat diperlukan dalam menghadapi masa depan yang selalu berubah. 


\section{Habits of Mind (HOM)}

Menurut Aristotle (Canfields \& Watkins, 2008), kesuksesan individu sangat ditentukan oleh kebiasaan-kebiasaan yang dilakukannya. Terdapat beberapa kebiasaan yang dilakukan oleh individu sukses dan kreatif sehingga membedakannya dengan individu-individu pada umumnya. Apa itu kebiasaan? Kebiasaan adalah perilaku yang dibentuk oleh pengulangan berkelanjutan (American Heritagc Dictionary, 1994). Kebiasaan yang dilakukan secara terus menerus akan semakin kuat dan menetap pada diri individu sehingga sulit diubah. Dalam hal ini kebiasaan tersebut telah membudaya pada diri individu.

Salah satu jenis kebiasaan yang dipandang sangat mempengaruhi kesuksesan individu adalah kebiasaan berpikir (habit of mind). Habits of Mind (HOM) mengisyratkan bahwa perilaku membutuhkan suatu kedisiplinan pikiran yang dilatih sedemikian rupa, sehingga menjadi kebiasaan untuk berusaha terus melakukan tindakan yang lebih bijak dan cerdas. Hal ini dapat dipahami karena segala bentuk tindakan yang dilakukan oleh seorang individu merupakan konsekuensi dari kebiasaan berpikirnya. Costa dan Kallick (2008) mendefinisikan kebiasaan berpikir sebagai kecenderungan untuk berperilaku secara intelektual atau cerdas ketika menghadapi masalah, khususnya masalah yang tidak dengan segera diketahui solusinya. Ketika menghadapi masalah, siswa cenderung membentuk pola perilaku intelektual tertentu yang dapat mendorong kesuksesan individu dalam menyelesaikan masalah tersebut.

Dalam konteks matematika, Millman dan Jacobbe (2008) mengidentifikasi beberapa kebiasaan berpikir matematis sebagai berikut.

a. Mengeksplorasi ide-ide matematis.

b. Merefleksi kebenaran jawaban.

c. Mengidentitikasi strategi pemecahan masalah yang dapat diterapkan untuk menyelesaikan masalah dalam skala lebih luas .

d. Bertanya pada diri sendiri apakah terdapat "sesuatu yang lebih" dan aktivitas matematika yang telah dilakukan (generalisasi).

e. Memformulasi pertanyaan.

f. Mengkonstruksi contoh.

Kemudian, Costa dan Kallick (2008) mengidentifikasi enambelas karakteristik kebiasaan berpikir tersebut yaitu sebagai berikut:

1) Bertahan atau pantang menyerah. Ketika menghadapi masalah, individu berusaha menganalisa masalah, kemudian mengembangkan sistem, struktur, atau strategi untuk memecahkan masalah tersebut, dan ketika ia gagal menerapkan suatu strategi, ia segera mencari alternatif solusi lainnya. Individu yang tidak memiliki sifat bertahan ketika menghadapi masalah, maka ia akan 
mudah frustrasi, merasa tidak berdaya, dan tidak mampu menyelesaikan masalah tadi.

2) Mengatur kata hati. Individu yang dapat mengatur kata hatinya akan berpikir reflektif dan berhati-hati. Sebelum bertindak ia menyusun rencana kegiatan, berusaha memahami petunjuk untuk merancang strategi, kemudian mengumpulkan informasi yang relevan, serta mempertimbangkan beragam alternatif dan konsekuensinya.

3) Mendengarkan pendapat orang lain dengan rasa empati. Pendengar yang baik bukan berarti ia selalu setuju dengan pendapat orang lain tetapi ia mencoba memahami pendapat orang lain dengan rasa empati.

4) Berpikir luwes. Individu yang berpikir luwes dan reflektif tetap menunjukkan rasa percaya diri, namun ia bersifat terbuka dan mampu mengubah pandangannya ketika memperoleh informasi tambahan.

5) Berpikir metakognitif. Individu yang berpikir metakognitif akan memahami apa yang diketahui dan yang tidak diketahuinya, memperkirakan sesuatu secara komparatif, serta memonitor pikirannya, persepsinya, keputusannya dan perilakunya.

6) Berusaha bekerja teliti dan tepat. Individu dengan karakteristik ini akan menghargai pekerjaan orang lain, bekerja teliti, berusaha mencapai standar yang tinggi, dan belajar berkelanjutan, dan berusaha memperbaiki yang dikerjakannya untuk memperoleh hasil yang lebih akurat.

7) Bertanya dan mengajukan masalah secara efektif. Individu dengan karakteristik ini ketika bertanya disertai dengan permintaan data pendukung, penjelasan, dan atau informasi yang relevan.

8) Memanfaatkan pengalaman lama untuk membentuk pengetahuan baru, Individu dengan karakteristik ini akan melakukan analogi dan berusaha mengaitkan pengalaman lama terhadap kasus serupa yang dihadapi

9) Berpikir dan berkomunikasi secara jelas dan tepat. Individu dengan karakteristik ini berkomunikasi dan mendefinisikan istilah dengan hati-hati, menggunakan bahasa yang tepat, nama yang benar, dan menghindar generalisasi yang berlebihan.

10) Memanfaatkan indera dalam mengumpulkan dan mengolah data. Individu dengan karakteristik ini memanfaatkan indera yang tajam, berpikir intuitif dan memperkirakan solusi sebelum tugas diselesaikan secara analitik.

11) Mencipta, berkayal, dan berinovasi. Individu dengan karakteristik ini memandang masalah dari sudut pandang yang berbeda, dan memiliki motivasi intrinsik.

12) Bersemangat dalam merespons. Individu dengan karakteristik ini bekerja dengan penuh semangat, dan senang melakukannya.

13) Berani bertanggung jawab dan menghadapi resiko. Individu yang memiliki karakteristik ini tidak takut gagal, dapat menerima ketidakpastian disertai dengan resiko yang diperkirakan.

14) Humoris. Individu yang humoris memandang situasi yang dihadapi sebagai sesuatu yang penting, dan memberikan apresiasi ke pada orang lain. 
15) Berpikir saling bergantungan. Manusia sebagai mahluk sosial selalu berberhubungan dengan manusia lainnya,. saling membutuhan, saling memberi dan menerima, dan lebih berpandangan kekitaan dari pada keakuan.

16) Belajar berkelanjutan. Sejalan dengan pandangan belajar sepanjang hayat, manusia akan belajar berkelanjutan, mencari sesuatu yang baru dan lebih baik, berusaha meningkatkan diri, dan memandang masalah, situasi, tekanan, konflik, dan lingkungan sebagai peluang untuk maju.

Dengan demikian, pandangan Millman dan Jacobbe (2008) serta ke-enambelas karakteristik kebiasaan berpikir (habits of mind) di atas, dapat dikembangkan dalam pembelajaran matematika, untuk mengembangkan kemampuan-kemampuan berpikir matematis, misalnya kemampuan berpikir kritis dan kreatif matematis, dan kemampuan pemecahan masalah matematis melalui pengembangan kebiasaankebiasaan berpikir matematis siswa.

\section{Strategi Habit of Minds Matematis dalam Pembelajaran Matematika}

Kebiasaan berpikir dalam matematika dikenal dengan istilah mathematical habits of mind (MHM). Cuoco (2010) mengungkapkan bahwa MHM mendorong kemampuan siswa untuk membuat koneksi antara ide-ide matematika. Hal ini berdasarkan hasil penelitian Ritchart \& Tishman dalam (Costa, 2000) dengan objek murid-murid dari kelas dasar, menengah sampai akhir meneliti tentang kemampuan mereka melalui pemberian berbagai tugas yang menggunakan soal-soal cerita, menunjukkan bahwa MHM dapat mewaspadai penurunan kemampuan berpikir siswa. Hal ini menunjukkan bahwa pentingnya habits of mind matematis dalam pembelajaran matematika sebagai transisi berpikir yang dapat diterapkan untuk materi yang tingkatannya lebih tinggi.

Strategi Habits of Mind (HOM) matematis adalah sebuah strategi untuk mengembangkan kemampuan berpikir melalui pembiasaan atau pembudayaan berpikir. Millman dan Jacobbe (2008) mengatakan bahwa strategi tersebut terdiri dari enam komponen, yaitu: mengeksplorasi ide-ide matematis, merefleksi kesesuian atau kebenaran jawaban, mengidentifikasi strategi pemecahan masalah untuk diterapkan pada skala yang lebih luas, bertanya pada diri sendiri tentang aktivitas matematika yang telah dilakukan, memformulasi pertanyaan, dan mengkonstruksi contoh. Pembiasaan dan pembudayaan berpikir seperti di atas yang berlangsung bersinambungan memberi peluang tumbuhnya kemampuan disposisi pada diri siswa. Kebiasaan-kebiasaan seperti di atas bila dilakukan secara konsisten dan berkelanjutan akan berimplikasi pada terbentuknya kemampuan (ability) dalam diri siswa. Misalnya kemampuan berpikir kritis, kreatif, dan atau kemampuan pemecahan masalah matematis siswa. 
Dalam pembelajaran dengan strategi HOM matematis, aktivitas- mengeksplorasi ide-ide matematis akan mendorong siswa untuk memahami masalah dengan baik. Hal ini menunjukkan bahwa penerapan strategi HOM matematis dalam pembelajaran matematika berpotensi untuk mengembangkan kemampuan pemecahan masalah. Hal itu didukung hasil penelitian Jacobbe (Millman dan Jacobbe, 2008) yang menunjukkan bahwa penggunaan strategi dengan melibatkan enam komponen tersebut dapat meningkatkan kinerja siswa dalam menyelesaikan masalah.

Berikut diuraikan komponen-komponen strategi HOM matematis beserta perannya dalam pengembangan kemampuan berpikir matematis siswa.

\section{1) Mengeksplorasi ide-ide matematis}

Eksplorasi ide-ide matematis mencakup identifikasi data, fakta, informasi , atau strategi pemecahan masalah yang sesuai. Dalam hal ini, untuk mengeksplorasi ideide matematis dapat digunakan teknik brainstorming. Menurut Costa dan Kallick (2008), brainstorming adalah strategi pengembangan ide yang digunakan secara kelompok sedemikian sehingga setiap anggota kelompok secara, bebas mengemukakan ide-idenya. Ide kunci brainstorming adalah penggunaan suatu ide untuk menstimulasi munculnya ide-ide lainnya. Selama proses brainstorming, semua ide diterima, direkam, dan tidak dikritisi dengan selanjutnya ide-ide tersebut ditinjau kesesuaiannya.

Prinsip yang dapat digunakan untuk mendorong siswa dalam mengeksplorasi ide-ide matematis adalah menunda evaluasi, memedulikan kuantitas, memberikan kebebesan berpikir. Prinsip menunda evaluasi dimaksudkan adalah menekankan agar guru tidak segera mengevaluasi atau menilai kebenaran atau kesesuaian suatu ide dan dikemukakan siswa. Prinsip memedulikan kuantitas menekankan pada pentingnya pengembangan sebanyak mungkin ide. Jika terdapat ide-ide yang secara kuantitas memadai, maka peluang untuk memperoleh ide yang berkualitas semakin besar. Prinsip memberikan kebebasan berpikir menekankan pada pemberian kebebasan kepada siswa untuk menghasilkan ide-ide yang tidak biasa. Menurut Takahashi (2006), untuk lebih mengembangkan kebiasaan siswa dalam mengeksplorasi ide-ide matematis, pembelajaran matematika dapat menggunakan soal terbuka (open ended problem), yang mempunyai banyak solusi atau strategi penyelesaian. Soal terbuka memungkinkan siswa menjadi lebih aktif dalam mengekspresikan ide-ide mereka dalam pembelajaran matematika. Dengan soal terbuka, siswa juga mempunyai banyak kesempatan untuk secara kemprehensif menggunakan pengetahuan dan keterampilan mereka.

Dengan demikian, penerapan strategi HOM matematis, yang salah satu komponennya adalah mengeksplorasi ide-ide matematis, berpotensi untuk 
menumbuhkan kemampuan berpikir kreatif. disposisi matematis, dan persepsi terhadap kreativitas.

\section{2) Merefleksi kesesuaian atau kebenaran jawaban}

Komponen berikutnya dari strategi HOM Matematis adalah merefleksi kesesuaian atau kebenaran jawaban. Komponen ini merupakan representasi dari tahapan lookina back (evaluaate solution) pada model pemecahan masalah Polya (1973), yaitu mengevaluasi atau menelaah kembali kesesuaian atau kebenaran solusi. Merefleksi kesesuaian jawaban maupun strategi pemecahan masalah penting dilakukan dalam proses pemecahan masalah maupun dalam kegiatan pembelajaran matematika secara umum. Tahapan merefleksi atau lookina, back menurut Millman dan Jacobbe (2008) dapat membantu mengkonsolidasi pengetahuan siswa dan menata pemikirannya serta mengembangkan kemampuannya untuk menyelesaikan masalah.

Pada umumnya, melakukan refleksi belum menjadi kebiasaan siswa pada umumnya. Menurut Mould dan Ragen (2008), pada kenyataannya, siswa sering tidak menyadari apa yang mereka pikir dan lakukan. Ketika ditanya, "bagaimana kamu menyelesaikan masalah itu?", sering siswa menjawab, "saya tidak tahu, saya hanya mengerjakannya". Mereka tidak mampu menjelaskan langkah-langkah yang mereka gunakan untuk menyelesaikan masalah. Mereka tidak dapat mentransformasi ide-ide mereka dalam bentuk kalimat yang jelas dan bisa dipahami orang lain. Terhadap hal ini, guru dapat mendorong siswa melakukan refleksi dengan mengajukan pertanyaan-pertanyaan seperti: "bagaimana kamu menyelesaikan masalah itu?", "bagaimana kamu mengetahui bahwa jawabanmu benar?", "apakah ada cara lain untuk menyelesaikan masalah ini?", dan sebagainya.

\section{3) Memformulasi pertanyaan}

Menurut Einstein (Costa dan Kallick, 2008), memformulasi pertanyaan atau masalah sering lebih esensial daripada solusi masalah itu sendiri. Mengajukan pertanyaan adalah aktivitas yang biasa dilakukan guru untuk melihat kemungkinan baru dari masalah lama adalah sangat penting dalam menstimulasi kemampuan berpikir siswa. Sesuai dengan kecenderungan pembelajaran matematika saat ini yang lebih mengedepankan aktivitas siswa dalam membangun makna atau pengetahuannya, guru perlu memberikan kesempatan kepada siswa untuk secara aktif membangun kemampuan bertanya. Mengembangkan kebiasaan bertanya dapat menumbuhkan kemampuan berpikir kreatif.

Berdasarkan penelitian Leung (1997), terdapat hubungan yang signifikan antara kemampuan berpikir kreatif dan kemampuan mengajukan pertanyaan. Sedangkan menurut Killpatrik (Christou et al, 1999), kualitas pertanyaan yang dibuat siswa menggambarkan kemampuan siswa menyelesaikan masalah. Aktivitas bertanya juga dapat penumbuhkan salah satu aspek disposisi matematis, yakni keingintahuan 
(curiosity). Dengan mengajukan pertanyaan yang berkaitan dengan situasi atau masalah, keingintahuan siswa semakin berkembang.

Dalam penelitian Leung, jenis pertanyaan yang dikembangkan agar menjadi kebiasaan siswa adalah "what if not ...?" atau "what happen if ...?" Pertanyaan jenis demikian akan mendorong siswa menghasilkan ide-ide kreatif. Serupa dengan hasil penelitian Wardani (2009), penggunaan teknik: bertanya "what if not" dalam pembelajaran dengan pendekatan inquiri dapat mengembangkan kemampuan berpikir kreatif siswa. Jenis pertanyaan ini dapat digunakan untuk memodifikasi situasi atau syarat yang terdapat pada soal-soal yang telah diselesaikan. Siswa dapat mengubah atau menambah informasi atau data pada soal semula, mengubah nilai data yang diberikan, tetapi tetap mempertahankan kondisi atau situasi soal semula, dan mengubah situasi atau kondisi soal semula, tetapi tetap mempertahankan data atau informasi yang ada pada soal semula.

\section{4) Generalisasi}

Komponen berikutnya dalam strategi HOM matematis adalah mengidentifikasi apakah terdapat "sesuatu yang lebih" dari aktivitas matematika yang dilakukan dan mengidentifikasi strategi pemecahan masalah yang dapat diterapkan pada masalah dalam skala lebih luas. Kedua komponen ini sesungguhnya adalah menggeneralisasi yakni menggeneralisasi pengetahuan atau konsep dan strategi pemecahan masalah.

Ketika menghadapi masalah, siswa didorong untuk menggunakan strategi yang bersifat informal untuk menyelesaikan masalah tersebut. Menurut Lim (2009), guru sebaiknya tidak mengenalkan algoritma atau strategi formal terlalu dini kepada siswa untuk menyelesaikan masalah. Siswa perlu diberikan kesempatan untuk menggunakan algoritma atau formula mereka sendiri berdasarkan pengetahuan yang mereka ketahui. Selanjutnya siswa melakuan proses metakognitif untuk memeriksa apakah strategi penyelesaian masalah yang digunakan dapat diterapkan pada masalah dalam skala lebih luas. Proses metakognitif juga dilakukan untuk memeriksa atau mengidentifikasi apakah proses yang dilakukan siswa mengarah pada penemuan suatu konsep matematis.

Guru perlu membantu siswa untuk melakukan generalisasi, misalnya dengan mengajukan pertanyaan-pertanyaan yang memberikan acuan. Dalam hal ini menurut Goetz (2004), beberapa jenis pertanyaan yang dapat diajukan adalah: "apa yang terjadi jika ...?", "bagaimana jika tidak?", "apakah kamu dapat melihat polanya?", "apakah kamu dapat memprediksi pola berikutnya?", "apakah kesamaan dan perbedaan strategi penyelesaian yang kamu gunakan dengan strategi temanmu?", "apakah strategi yang kamu gunakan dapat digunakan untuk menyelesikan masalah lain?", dan sebagainya. 
Aktivitas menggeneralisasi mengarah pada konstruksi konsep-konsep matematis maupun strategi penyelesaian masalah yang bersifat umum. Hal demikian sejalan dengan pandangan konstruktivisme (Hein, 1996), yakni siswa secara aktif mengkonstruksi sendiri. Aktivitas demikian juga berpotensi menumbuhkan kemampuan berpikir kreatif. Siswa didorong untuk berpikir fleksibel dalam mengeksplorasi berbagai strategi penyelesaian masalah yang sesuai. Aktivitas demikian sangat mungkin akan menghasilkan strategi pemecahan masalah yang bersifat unik atau baru, setidaknya bagi siswa atau kelompok siswa yang menemukannya.

\section{5) Mengkonstruksi contoh}

Menurut Liz et al (2006), pemberian contoh berperan penting dalam pengembangan matematika sebagai disiplin ilmu dan dalam pembelajaran matematika. Suatu konsep yang abstrak dan kompleks menjadi relatif mudah dipahami bila diberikan contoh-contoh yang sesuai. Sejalan dengan itu, Ia mengklasifikasikan tiga jenis contoh, yaitu contoh generik atau contoh umum (genenic example), contoh penyangkal atau lawan contoh (counter-ewenzple), dan atau non-contoh (nonexample). Contoh generik adalah contoh suatu konsep, prosedur, atau teorema yang bersifat umum. Contoh penyangkal digunakan untuk menguji berlakunya suatu dugaan atau konjektur sebelum membuktikannya secara formal . Sedangkan noncontoh digunakan untuk memperjelas definisi suatu konsep. Pemberian non-contoh akan memperjelas apakah suatu objek merupakan contoh konsep atau bukan.

Dalam pembelajaran matematika, siswa perlu diberikan kesempatan untuk mengkonstruksi contoh. Menurut Zaslavsky (Liz et al, 2006), memberikan kesempatan kepada siswa untuk menukonstruksi contoh merupakan strategi efektif untuk mengubah insiatif dari guru kepada siswa. Manfaatnya adalah guru dapat mendeteksi ketidakpahaman siswa yang tercermin dari contoh yang dikonstruksi siswa tersebut. Menurut Dahlberg dan Housman (Liz et al, 2006), mengkonstruksi contoh merupakan tugas kompleks yang menuntut kemampuan siswa untuk mengaitkan beberapa konsep. Jika siswa tidak diberikan kesempatan untuk mengkonstruksi berbagai jenis contoh, terlebih contoh penyangkal atau non-contoh, dimungkinkan siswa akan membuat generalisasi yang tidak tepat.

Oleh karena itu, penting bagi guru untuk memberikan tugas yang memungkinkan siswa memberikan reaksi "saya mampu mengerjakannya". Keyakinan diri siswa tidak dapat dibangun secara terpisah dari kesuksesan siswa dalam mengerjakan tugas. Ketika siswa menyadari bahwa mereka mampu melakukan tugas dengan baik, keyakinan diri merekapun tumbuh. Hal ini menunjukkan bahwa mengembangkan kebiasaan mengkonstruksi contoh akan berimplikasi pada terbentuknya kemampuan berpikir kreatif. Watson dan Mason (Millman \& Jacobbe, 2008) berpendapat bahwa salah satu strategi yang dapat digunakan untuk menumbuhkan kreativitas siswa 
adalah dengan memberikan kesempatan kepada siswa untuk mengkonstruksi contohcontoh mereka sendiri.

Mengkonstruksi contoh juga dapat menumbuhkan kemampuan disposisi matematis siswa. Siswa yang mampu mengkonstruksi contoh sesuai dengan kriteria tertentu akan memiliki kepercayaan diri, yang merupakan salah satu aspek matematis.

Berikut ini disajikan contoh soal mengenai strategi HOM matematis dalam pembelajaran matematika:

(1) Perhatikan gambar di bawah ini!

Diketahui: Titik E, F, G, dan $\mathrm{H}$ adalah titik-titik tengah dari sisi-sisi persegi $\mathrm{ABCD}$, titik I, J, K, dan L adalah titik-titik tengah dari sisi-sisi persegi EFGH, dan titik M, N, O, dan P adalah titik-titik tengah dari sisi-sisi persegi IJKL .

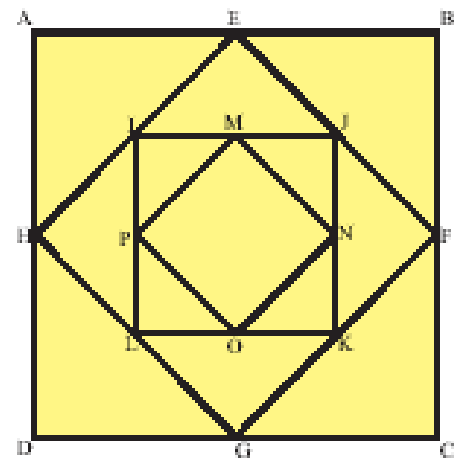

Pertanyaan

a. Misalkan: luas ABCD mewakili bilangan 1, bilangan berapakah yang mewakili luas daerah EFGH, IJKL, dan MNOP?Mengapa?

b. Berapa bagian luas daerah IJKL dari luas daerah EFGH? Mengapa?

c. Berapa bagian luas daerah MNOP dari luas daerah IJKL? Mengapa?

d. Berapa bagian luas daerah MNOP dari luas daerah EFGH? Mengapa?

e. Bilangan berapakah yang mewakili potongan E? Mengapa?

(2) Perhatikan gambar berikut!

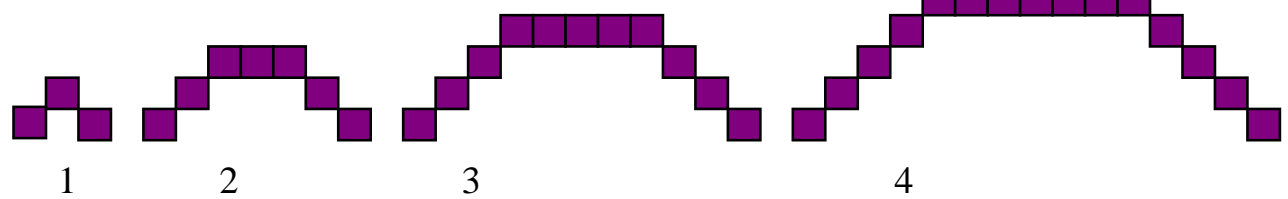

a. Berapa banyak ubin yang terdapat pada gambar ke 20?

b. Temukan suatu pola, untuk menentukan banyaknya ubin pada gambar ke350 
(3) Pak Adam sedang menghitung biaya produkksi membuat gantungan kunci. Tiap gantungan kunci memuat dua huruf yang berbeda tanpa mempertimbangkan urutan huruf. Beberapa contoh banyaknya huruf dan banyaknya gantungan kunci yang dapat dibuat tercantum pada Tabel berikut:

\begin{tabular}{|l|l|}
\hline $\begin{array}{l}\text { Banyaknya } \\
\text { huruf }\end{array}$ & $\begin{array}{l}\text { Banyaknya } \\
\text { gantungan kunci }\end{array}$ \\
\hline 4 & 12 \\
\hline 5 & 20 \\
\hline 6 & 30 \\
\hline 7 & 42 \\
\hline 8 & 56 \\
\hline
\end{tabular}

Berdasarkan data di atas, pak Adam mengestimasi bahwa dari 50 huruf yang berbeda ia akan mendapat 2450 buah gantungan kunci. Estimasi pak Adam adalah (pilih salah satu jawaban dan berikan penjelasanmu)
a. Pasti benar
c. Data tidak cukup
e. Pasti salah
b. Mungkin benar
d. Mungkin salah

\section{PENUTUP}

Dari uraian di atas dapat disimpulkan bahwa:

1. Habits Of Mind (HOM) adalah kebiasaan berpikir secara fleksibel, mengelola secara empulsif, mendengarkan dengan empati, membiasakan mengajukan pertanyaan, kebiasaan menyelesaikan masalah secara efektif, membiasakan menggunakan pengetahuan masa lalu untuk situasi baru, membiasakan berkomunikasi, berpikir jernih dengan tepat, menggunakan semua indera ketika mengumpulkan informasi, mencoba cara berbeda dan menghasilkan ide-ide yang baru, kebiasaan untuk merespon, kebiasaan untuk mengambil resiko, biasa bertanggung jawab, memiliki rasa humor, membiasakan berpikir interaktif dengan orang lain, bersikap terbuka dan mencoba terus-menerus.

2. Kesuksesan individu sangat ditentukan oleh kebiasaan-kebiasaan yang dilakukannya, secara terus menerus akan semakin kuat dan menetap pada diri individu sehingga sulit diubah. Perilaku tersebut membutuhkan suatu kedisiplinan pikiran yang dilatih sedemikian rupa, sehingga menjadi kebiasaan untuk berusaha terus melakukan tindakan yang lebih bijak dan cerdas.

3. Strategi HOM matematis terdiri dari enam komponen, yaitu: mengeksplorasi ide-ide matematis, merefleksi kesesuian atau kebenaran jawaban, mengidentifikasi strategi pemecahan masalah pada skala yang lebih luas, bertanya pada diri sendiri tentang aktivitas matematika yang telah dilakukan, 
memformulasi pertanyaan, dan mengkonstruksi contoh. Kebiasaan-kebiasaan seperti di atas perlu dilakukan secara konsisten dan berkelanjutan dalam pembelajaran maka akan menghasilkan peserta didik yang unggul dalam kemampuan berpikir matematis dan yang terpuji.

\section{DAFTAR PUSTAKA}

Costa, A. dan Kallick, B. (2008). Describing 16 Habits of Mind. [Online]. Tersedia: http://www.habits-of-mind.net/pdf/16HOM2.pdf. [17 April 2013].

Cuoco, AL., J. et al. (2010). Habits of Mind. An Organizing Principle For Mathematcs Curricula. Journal of Mathematical Behavior 15, 375-402.

Departemen Pendidikan Nasional, (2004). Kurikulum 2004. Standar Kompetensi Mata Pelajaran Matematika, Puskur, Jakarta.

Goetz, J. (2004). Top Ten Thoughts about Communication in Mathematics. [Online]. Tersedia: http://www.kent.k12.wa.us/KSD/IS/communication_ in_math.htm. [7 Oktober 2013].

Goldenberg.et.al (2002) . "Mathematical Habits of Mind Young Children" [ Online]. Tersedia: http//www.google.com [29 April 2013].

Hein,G.E.(1996).Constructivism Learning Theory. [Online]. Tersedia: http://www.exploratorium.edu/ifi/resources/constructivistlearning.html.[25 Mei 2013]

Lim, K. (2009). Undesirable Habits of Mind of Pre-service Teachers: Strategies for Addressing Them.[Online]. Tersedia: http://www.math.utep. edu/Faculty/kienlim/HOM_2009_Lim.pdf. [5 September 2013]

Liz, B et al. (2006). Exemplification in Mathematics Education. Dalam Proceeding of the 30th Conference of the International Group for the Psychology of Mathematics Education. [Online]. Tersedia: http://mcs. open.ac.uk/jhm3/PME30RF/PME30RFPaper.pdf. 13 Juli 2013]

Mahmudi, A. (2010). Pengaruh Pembelajaran dengan Strategi MHOM Berbasis Masalah terhadap Kemampuan Berpikir Kreatif, Kemampuan Pemecahan Masalah, dan Disposisi Matematis, serta Persepsi terhadap Kreativitas. Disertasi pada Sekolah pascasarjana UPI. Diterbitkan pada Jurnal Educationist, UPI, Januari 2011.

Millman, R.S. \& Jacobbe, T. (2008). Fostering Creativity in Preservice Teachers Through Mathematical Habits of Mind. Proceeding of the Discussing Group 9. The $11^{\text {th }}$ International Congress on Mathematical Education. Monterrey, Mexico, July 2012. [Online]. Tersedia: http://dg.icme11.org/document/ get/272. [10 November 2013].

Miliyawati, B. (2012). Peningkatan Kemampuan Berpikir Kritis dan Self-Efficacy Matematis Siswa SMA dengan Menggunakan Pendekatan Investigasi. Tesis pada PPs UPI Bandung: Tidak diterbitkan.

Mullis, I.V.S., Martin, M.O., Foy P., \& A. (2012). TIMSS 2011 International Result in Mathematics. Netherlands: IEA. 
Pearson Education. (2000). Mathematical Disposition. [Online] Tersedia: http://www.teachervision.fen.com/math/teacher-training/55328.html? for_printing=1. [24 Mei 2013]

Polya, G. (1973). How to Solve It. A New Aspect of Mathematical Method. New Jersey: Princenton University Press

Slavin, R.E (2000). Education Psychology: Theory and Practice. Sixth Edition. Boston: Allyn and Bacon.

Sumarmo. (2010). Berpikir Matematik, Apa, Mengapa, dan bagaimana Dikembangkan pada peserta didik. Bandung: Makalah Tidak Dipublikasikan.

Umar, W. (2013). Pengembangan Mathematical Thinking Berorientasi pada Gaya Kognitif dan Budaya Siswa. Makalah diterbitkan pada jurnal pendidikan Matematika UM. Malang 